\title{
The Location of a Temperature-sensitive trans-Dominant Mutation and Its Effect on Restriction and Modification in Escherichia coli K12
}

\author{
By JOSEF HUBÁČEK, ${ }^{1 *}$ VITALY E. ZINKEVICH ${ }^{2}$ AND \\ MARIE WEISEROVÁ ${ }^{1}$ \\ ${ }^{1}$ Institute of Microbiology, Czechoslovak Academy of Sciences, Videňská 1083, \\ 14220 Prague 4, Czechoslovakia \\ 2 Institute of Biochemistry and Physiology of Micro-organisms, USSR Academy of Sciences, \\ Puschino on the Oka, Moscow Region, USSR
}

(Received 31 March 1989; revised 4 July 1989; accepted 4 August 1989)

\begin{abstract}
An Escherichia coli $\mathrm{K} 12$ chromosomal EcoRI-BamHI fragment containing a mutant $h s d S$ locus was cloned into plasmid pBR322. The $\operatorname{mcr} B$ gene, closely linked to $h s d S$, was used for selection

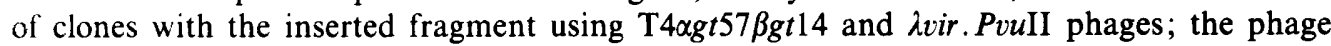
DNAs contain methylated cytosines and hence can be used to demonstrate McrB restriction. For the efficient expression of the $h s d S$ gene, a $B g l$ II fragment of phage $\lambda$ carrying the $p_{\mathrm{R}}$ promoter was inserted into the BamHI site of the hybrid plasmid. Under these conditions a trans-dominant effect of the $h s d X_{\mathrm{ts}}^{+\mathrm{d}}$ mutation on restriction and modification was detected. Inactivation of the $h s d S$ gene by the insertion of the $\lambda$ phage $B g l$ II fragment into the $B g l$ II site within this gene resulted in the disappearance of the trans-dominant effect. When the cloned BamHI-EcoRI fragment was shortened by $H p a \mathrm{I}$ and EcoRI restriction enzymes, the transdominant effect was fully expressed. The results indicate that the $X_{\mathrm{ts}}^{+\mathrm{d}}$ mutation is located in the $h s d S$ gene. The effect of gene dosage of the HsdS subunit on the expression of $X_{\mathrm{ts}}^{+\mathrm{d}}$ mutation was studied. The results of complementation experiments, using $\mathrm{F}^{\prime}$-merodiploids or plasmid pBR322 with an inserted $X_{\mathrm{ts}}^{+\mathrm{d}}$ mutation, support the idea that the $\mathrm{Hsd} \mathrm{S}_{\mathrm{ts}}^{+\mathrm{d}}$ product competes with the wild-type HsdS product, and has a quantitatively different effect on restriction and modification
\end{abstract}

\section{INTRODUCTION}

Knowledge of the structural and functional organization of the genes coding for type I restriction and modification enzymes is important not only for the elucidation of the mechanisms of regulation of gene activity, but also for studies of protein-protein and protein-nucleic acid interactions (Sain \& Murray, 1980; Burckhardt et al., 1981). Type I restriction endonucleases are encoded by three chromosomal genes: $h s d R, h s d M$ and $h s d S$. Genetic experiments have shown that the corresponding polypeptides $R, M$ and $S$ can be interchanged between related systems and have identified the $S$ subunit as the determinant of the specificity of restriction (Boyer \& Roulland-Dussoix, 1969; Hubáček \& Glover, 1970; Van Pal \& Colson, 1974).

Using a genetic approach we analysed a temperature-sensitive (ts) mutation affecting restriction and modification in Escherichia coli K12 (Hubáček \& Weiserová, 1980). The results demonstrated its location outside the $h s d R$ and $h s d M$ genes and its trans-dominant $\left(\mathrm{d}^{+}\right)$nature (Hubáček \& Kossykh, 1982). The high frequency of recombination between $h s d R$ and $h s d X_{\mathrm{ts}}^{+\mathrm{d}}$ mutations led us to postulate an additional gene to the $h s d$ three-gene complex which affects the expression of the R-M phenotype (Hubáček \& Weiserová, 1985).

Genetic analysis of the $E$. coli $\mathrm{rglA}$ and $\mathrm{rglB}$ restriction systems, which were reported to degrade the DNA of T-even phages when the DNA contained 5-hydroxymethylcytosine in a nonglucosylated state, positioned $\mathrm{rglA}$ at $25.24 \mathrm{~min}$ and $\mathrm{rglB}$ at $98.39 \mathrm{~min}$ on the chromosome 
(Ravi et al., 1985). Recently the genetic region involved in McrB (= RglB) restriction of 5-methylcytosine DNA has been cloned and located on a $5500 \mathrm{bp} \mathrm{BglII-EcoRI} \mathrm{fragment}$ proximal to the $h s d$ genes of $E$. coli K 12 and closely linked to $h s d S$ (Raleigh \& Wilson, 1986; Ross \& Braymer, 1987).

In the present work, new data on the location of the $h s d X_{\mathrm{ts}}^{+\mathrm{d}}$ mutation were obtained by gene cloning techniques, using the $m c r B$ gene as a selective marker. The gene dosage of the wild-type HsdS product was found to affect the expression of the $h s d X_{\mathrm{ts}}^{+\mathrm{d}}$ mutation and vice versa.

\section{METHODS}

Plasmids and bacteriophages. pBR322 (Bolivar et al., 1977), גvir and P1CMclr100, the thermoinducible mutant of PICM (Rosner, 1972), were used. Recombinant plasmids $\mathrm{pMS}_{\mathrm{K}} 14, \mathrm{pMS}_{\mathrm{K}} 41, \mathrm{pMS}_{\mathrm{K}} \mathrm{C23}, \mathrm{pMS}_{\mathrm{K}} \mathrm{V} 14_{4}$ and $\mathrm{pMS}_{\mathrm{K}} \mathrm{V} 7$

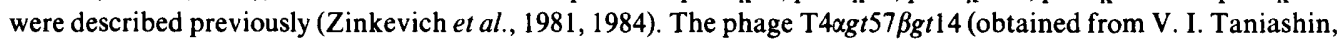
USSR Academy of Sciences, Puschino on the Oka, USSR) grown on E. coli rglA rglB was used to estimate McrB $(=\mathrm{RglB})$ and McrA ( = RglA) activities. The phage DNA is nonglucosylated and contains 5-hydroxymethylcytosine. The activity of the $m c r B(=r g l B)$ gene was tested using the phage $2 v i r$. PvuII. The phage was modified during its growth on $E$. coli carrying a plasmid with the $P v u I I$ restriction-modification system (kindly supplied by V. M. Kramarov, USSR Academy of Sciences, Puschino on the Oka, USSR). DNA with PvuII methylated sites is the substrate for the action of the $r g l B$ system (Raleigh \& Wilson, 1986).

Bacteria. The $E$. coli strains used are described in Table 1.

Media and microbial methods. Bacterial and phage buffers, M9 medium, L-amino acid and vitamin supplements were used as described by Hubáček \& Glover (1970). The complex medium was L-broth solidified with $1 \cdot 5 \%(w / v)$ agar (soft agar with $0.6 \%, \mathrm{w} / \mathrm{v}$ ). Antibiotics were added at the following concentrations: ampicillin (Ap), $50 \mu \mathrm{g} \mathrm{ml}^{-1}$; tetracycline (Tc), $12.5 \mu \mathrm{g} \mathrm{ml}^{-1}$. Preparation of $\mathrm{F}^{\prime}$-factors, construction of $\mathrm{F}^{\prime}$-merodiploids and transduction procedure were as described previously (Hubáček \& Weiserová, 1980).

Testing of plating efficiencies on temperature-sensitive mutants. Bacteria $(0.2 \mathrm{ml})$ grown overnight at $30^{\circ} \mathrm{C}$ or $42^{\circ} \mathrm{C}$ in L-broth were suspended in $3 \mathrm{ml}$ soft agar with $0.01 \mathrm{M}-\mathrm{MgSO}_{4}$ and mixed with standard dilutions of $\lambda$ vir. $\mathrm{K}$ or $\lambda v i r . O$. At least $16 \mathrm{~h}$ growth at $42^{\circ} \mathrm{C}$ is needed to obtain the expression of the temperature-sensitive restriction phenotype of strain HfrH-90-XC with the $X_{t s}^{+d}$ mutation (Hubáček \& Kossykh, 1982). The cell suspensions were plated on L-agar immediately after mixing with phage. Restriction was scored with $\lambda$ vir. $\mathrm{K}$ and $\lambda$ vir. $\mathrm{O}$ by the method described by Hubáček \& Glover (1970). Modification was scored using standard indicator strains E. coli K and $\mathrm{C}$; the fraction of $\mathrm{K}$-plating phage produced is calculated as a function of the efficiency of plating (e.o.p.) on E. coli $\mathrm{C}$, which is taken as $1 \cdot 0$.

Preparation of DNA. Chromosomal DNA was prepared as described by Marmur (1961). Plasmid DNA for ethidium bromide $/ \mathrm{CsCl}$ equilibrium density-gradient centrifugation and for rapid small-scale isolation was prepared by the alkaline lysis method (Maniatis et al., 1982).

\section{Table 1. Escherichia coli strains}

Strain phenotype Other characteristics $\quad$ Source or reference

\begin{tabular}{|c|c|c|c|}
\hline Hfr-1 & $\mathbf{r}_{\mathrm{K}}^{+} \mathrm{m}_{\mathrm{K}}^{+}$ & thr thi & \\
\hline HfrH-90-XC & $r_{t s}^{+} m_{t s}^{+}$ & thi $h s d X_{\mathrm{ts}}^{+\mathrm{d}}$ & \\
\hline HfrH-IV & $\mathrm{r}_{\mathrm{K}}^{-} \mathrm{m}_{\overline{\mathrm{K}}}$ & thi hsdS & Hubáček \& Weiserová (1980) \\
\hline HfrJC 5088 & & thr ilv rec $A 56$ & \\
\hline AB2463 & $\mathrm{r}_{\mathrm{K}}^{+} \mathrm{m}_{\mathrm{K}}^{+}$ & thr leu arg pro his thi rec $A 13$ & \\
\hline $\mathrm{K} 802$ & $\mathrm{r}_{\mathrm{K}} \mathrm{m}_{\mathrm{K}}^{+}$ & met gal hsdR2 mcrA mcrB & \\
\hline K803 & $\mathrm{r}_{\mathrm{K}}^{-} \mathrm{m}_{\mathrm{K}}^{-}$ & met gal hsdS3 & Raleign et al. (1988) \\
\hline $\mathrm{C}$ & $\mathrm{r}^{-} \mathrm{m}^{-}$ & $\operatorname{ser} B$ & \\
\hline C600 & $\mathrm{r}_{\mathrm{K}}^{+} \mathrm{m}_{\mathrm{K}}^{+}$ & thr leu thi & Hubáček (1973) \\
\hline C600-5K & $\mathrm{r}_{\mathbf{K}}^{-} \mathbf{m}_{\mathbf{K}}^{+}$ & thr leu thi hsdR & \\
\hline C600-IV & $\mathbf{r}_{\mathbf{K}}^{-} \mathbf{m}_{\bar{K}}$ & leu thi hsdS & \\
\hline C600-5K thy & $\mathbf{r}_{\mathbf{K}}^{-} \mathrm{m}_{\mathrm{K}}^{+}$ & thr leu thy thi hsdR & thy derivative of $\mathrm{C} 600-5 \mathrm{~K}$ \\
\hline $5 \mathrm{~K}-76$ & $\mathrm{r}_{\mathrm{ts}}^{+} \mathrm{m}_{\mathrm{ts}}^{+}$ & leu thy thi hsd $X_{\mathrm{ts}}^{+\mathrm{d}}$ & $\mathrm{Thr}^{+} \mathrm{HsdX}_{\mathrm{ts}}^{+\mathrm{d}}$ transductant of $\mathrm{C} 600-5 \mathrm{~K}$ thy \\
\hline $5 \mathrm{~K}-76-19$ & $\mathrm{r}_{\mathrm{ts}}^{+} \mathrm{m}_{\mathrm{ts}}^{+}$ & leu thi hsd $X_{\mathrm{ts}}^{+\mathrm{d}}$ recA56 & rec $A$ derivative of $5 \mathrm{~K}-76$; this paper \\
\hline IV-28 & $\mathbf{r}_{\bar{K}} \mathbf{m}_{\bar{K}}^{-}$ & leu thy thi hsdS & thy derivative of $\mathrm{C} 600-\mathrm{IV}$ \\
\hline IV-28-1 & $\mathrm{r}_{\mathrm{K}} \mathrm{m}_{\overline{\mathrm{K}}}$ & leu thi hsdS recA56 & rec $A$ derivative of IV -28 \\
\hline NM273 & $\mathrm{r}_{\mathrm{B}}^{-} \mathrm{m}_{\overline{\mathrm{B}}}^{-}$ & $h s d R$ hsdM & $\begin{array}{l}\text { Kindly supplied by N. E. Murray, Univ. of } \\
\text { Edinburgh, UK }\end{array}$ \\
\hline M15 & & $\operatorname{lac} Z \Delta \mathrm{M} 15 \operatorname{rec} A$ & Ruther et al. (1981) \\
\hline P678-54 & & $\min A \min B$ & Adler et al. (1967) \\
\hline
\end{tabular}


Restriction, ligation, and gel electrophoresis. All experiments were done as described by Maniatis et al. (1982). Biochemicals and reagents. Restriction enzymes BamHI, Eco RI, BglII and $H p a I$, and T4 DNA ligase, were obtained from the Institute of Biochemistry and Physiology of Micro-organisms, USSR Academy of Sciences. MluI was prepared by I. Gavrilenko (USSR Academy of Sciences, Puschino on the Oka, USSR); HindIII was provided by the Institute of Applied Enzymology, Vilnius, USSR. Medium components were obtained from Oxoid.

\section{RESULTS AND DISCUSSION}

\section{Cloning of a DNA fragment containing the $h s d X_{\mathrm{ts}}^{+\mathrm{d}}$ mutation}

The following results do not resolve the location of the $h s d X_{\mathrm{ts}}^{+\mathrm{d}}$ mutation, but they point against its being located outside the $h s d$ three-gene complex as had been previously believed (Hubáček \& Weiserová, 1980).

E. coli $\mathrm{K} 802$ was crossed with the $\mathrm{HfrH}-90-\mathrm{XC} h s d X_{\mathrm{ts}}^{+\mathrm{d}}$ donor and after $25 \mathrm{~min}$ of conjugation the mating was interrupted by vortex shaking and $\mathrm{Gal}^{+}$recombinants were selected. Among the 40 purified colonies the unselected $\mathrm{McrB}^{+}$phenotype appeared in 12 recombinants with lowered

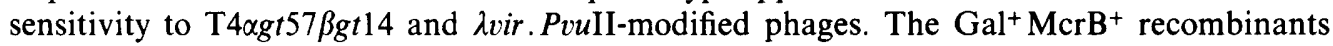
were tested for restriction and modification of phage $\lambda$ at $30^{\circ} \mathrm{C}$ and $42{ }^{\circ} \mathrm{C}$. Table 2 lists the two classes of different R-M phenotypes obtained, $\mathrm{r}_{\mathrm{ts}}^{+} \mathrm{m}_{\mathrm{ts}}^{+}$and $\mathrm{r}^{-} \mathrm{m}_{\mathrm{ts}}^{+}$. All the $\mathrm{McrB}^{+}$recombinants were temperature-sensitive in restriction or modification; three $\mathrm{McrB}^{+}$clones out of 12 were of the $\mathrm{r}^{-} \mathrm{m}_{\mathrm{ts}}^{+}$phenotype. The $h s d R$ mutation is separable by recombination from the $m c r B^{+}$gene and the $h s d X_{\mathrm{ts}}^{+\mathrm{d}}$ mutation and we can assume that the $X_{\mathrm{ts}}^{+\mathrm{d}}$ mutation is more closely linked to $m c r B$ than the $h s d R$ gene. The relatively high frequency of recombination between $h s d R$ and $m c r B$ mutations could indicate a rather higher frequency of recombination among the mutations located inside the $h s d$ complex locus or close to it than we considered previously (Hubáček \& Weiserová, 1980).

The structures and properties of recombinant $\mathrm{pMS}_{\mathrm{K}} 14, \mathrm{pMS}_{\mathrm{K}} \mathrm{C} 23$ and $\mathrm{pMS}_{\mathrm{K}} \mathrm{V} 17$ plasmid DNAs used in the following experiments are summarized in Fig. $1 . \mathrm{pMS}_{\mathrm{K}} 14$ is pBR322 with the $E c o$ RI-Bam HI fragment of the $h s d$ region containing the intact and very inefficiently expressed $h s d S_{\mathrm{K}}$ gene. This DNA, after digestion with BamHI and Sal I, served as a recipient of the BamHI-Sal I fragment from $\mathrm{pMS}_{\mathrm{K}} 41$ with the $h s d M$ gene and $\mathrm{p}_{\bmod }$ promoter. $\mathrm{Ap}^{\mathrm{R}}$ colonies were selected after ligation and transformation into $E$. coli $\mathrm{C}$. Some of them were found to modify the $\lambda$ vir. $O$ phage; the plasmid $\mathrm{pMS}_{\mathrm{K}} \mathrm{C} 23$ was thus obtained with efficiently expressed $h s d S_{\mathrm{K}}$ and $h s d M$ genes. Restriction analysis has shown that this plasmid contains an Eco RI-Sal I fragment which consists of a BamHI-SalI fragment from $\mathrm{pMS}_{\mathrm{K}} 41$ and an EcoRI-BamHI fragment from $\mathrm{pMS}_{\mathrm{K}} 14$. Plasmid $\mathrm{pMS}_{\mathrm{K}} \mathrm{C} 23$ has two recognition sites for $P v u I I$ and one each for $S m a \mathrm{I}$ and $H p a \mathrm{I}$. Their location made it possible to clone PvuII-SmaI and $\mathrm{HpaI}-\mathrm{SmaI}$ fragments into the PvuII site of pBR322, resulting in plasmids $\mathrm{pMS}_{\mathrm{K}} \mathrm{V} 14$ and $\mathrm{pMS}_{\mathrm{K}} \mathrm{V} 17$.

The recombinant plasmids $\mathrm{pMS}_{\mathrm{K}} 14, \mathrm{pMS}_{\mathrm{K}} \mathrm{C} 23$ and $\mathrm{pMS}_{\mathrm{K}} \mathrm{V} 17$ were transformed into the recipient strain $5 \mathrm{~K}-76-19\left(h s d X_{\mathrm{ts}}^{+\mathrm{d}}\right)$ and the selected $\mathrm{Ap}^{\mathrm{R}}$ clones were tested for restriction and modification at $30^{\circ} \mathrm{C}$ and $42{ }^{\circ} \mathrm{C}$ (Table 3). Complementation of the wild-type restriction and modification phenotypes was obtained in transformants with plasmid DNA in which the inefficient expression of the $h s d S$ gene in plasmid $\mathrm{pMS}_{\mathrm{K}} 14$ (Zinkevich et al., 1981; Table 3, expt 1) is improved by fusion with the BamHI-SalI fragment containing the intact hsdM gene (plasmid $\mathrm{pMS}_{\mathrm{K}} \mathrm{C} 23$, Table 3, expt 2). The EcoRI-Sal I fragment in $\mathrm{pMS}_{\mathrm{K}} \mathrm{C23}$, shortened by $H p a I$ and $S m a I$ to about $3.8 \mathrm{~kb}$ in length and cloned into the $\mathrm{pBR} 322$ to give $\mathrm{pMS}_{\mathrm{K}} \mathrm{V} 17$, carries only two genes, $h s d M$ and $h s d S$, which are expressed under the control of the $\mathrm{p}_{\text {mod }}$ promoter (Loenen et al., 1987); even under these conditions complementation of the wild-type R-M phenotype was obtained (Table 3, expt 3). The results indicate that the genetic region which is involved in the expression of temperature-sensitive restriction and modification is located on the $H p a I-S m a I$ fragment, on which the only functional genes are $h s d S$ and $h s d M$.

In further experiments we tried to clone the DNA fragment containing the $h s d X_{\mathrm{ts}}^{+\mathrm{d}}$ mutation. Chromosomal DNA from one of the $\mathrm{K} 802 \mathrm{Gal}^{+} \mathrm{McrB}^{+} \mathrm{r}_{\mathrm{ts}}^{+} \mathrm{m}_{\mathrm{ts}}^{+}$recombinants (Table 2) was used as the source of DNA. The $h s d S_{\mathrm{K}}$ and $m c r B$ genes are carried on an EcoRI-BamHI fragment 


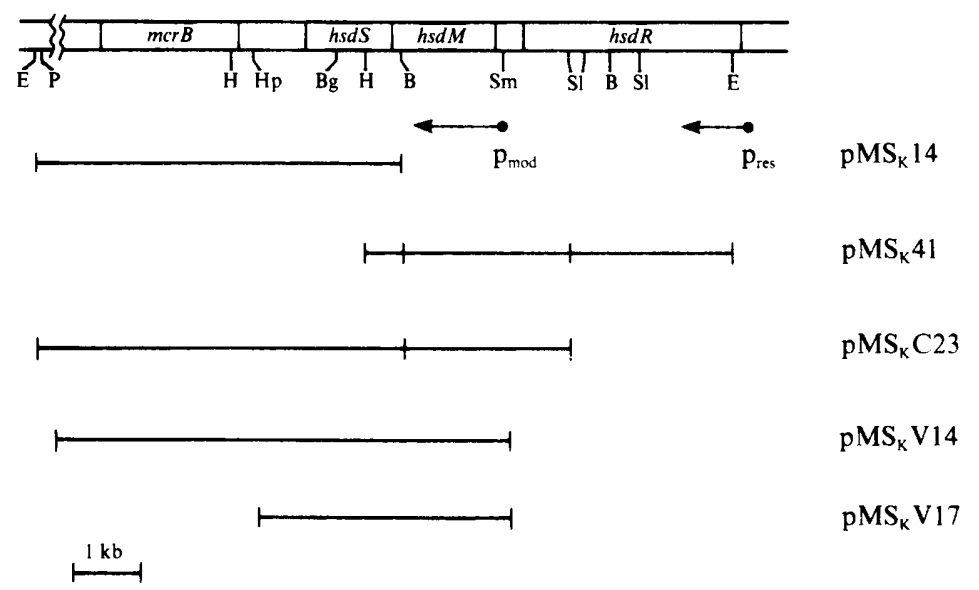

Fig. 1. Map of the hsd and $m c r$ genes and the location of recognition sites for different restriction enzymes (E, EcoRI; P, PvuII; B, BamHI; H, HindIII; Hp, HpaI; Bg, BglII; Sm, SmaI ; Sl, SalI). The hybrid plasmids with cloned fragments of the hsd region in pBR322 are shown. The relevant modification phenotypes of cells harbouring the hybrid plasmids are : $E$. coli $\mathrm{K}^{803}\left(\mathrm{pMS}_{\mathrm{K}} 14\right), \mathrm{m}_{\mathrm{K}} ; E$. coli $\mathrm{NM} 273\left(\mathrm{pMS}_{\mathrm{K}} 41\right), \mathrm{m}_{\mathrm{B}}^{+} ; E$. coli $\mathrm{C}\left(\mathrm{pMS}_{\mathrm{K}} \mathrm{C} 23\right), \mathrm{m}_{\mathrm{K}}^{+} ; E$. coli $\mathrm{C}\left(\mathrm{pMS}_{\mathrm{K}} \mathrm{V} 14\right), \mathrm{m}_{\mathrm{K}}^{+} ; E$. coli $\mathrm{C}\left(\mathrm{pMS}_{\mathrm{K}} \mathrm{V} 17\right), \mathrm{m}_{\mathrm{K}}^{+}$. The arrows indicate the direction of transcription.

Table 2. Restriction and modification phenotypes of $\mathrm{Gal}^{+} \mathrm{McrB}^{+}$recombinants resulting from a cross between $\mathrm{HfrH}-90-\mathrm{XC}\left(\mathrm{hsd} \mathrm{X}_{\mathrm{ts}}^{+\mathrm{d}}\right)$ as donor and $\mathrm{K} 802$ as recipient

\begin{tabular}{|c|c|c|c|c|}
\hline $\begin{array}{l}\text { Temp. } \\
\left({ }^{\circ} \mathrm{C}\right)^{*}\end{array}$ & $\begin{array}{l}\text { Restriction } \dagger \\
\lambda \text { vir. } \mathrm{O}\end{array}$ & $\begin{array}{c}\text { Modification } \dagger \\
\text { K }\end{array}$ & $\begin{array}{l}\text { Phenotype of } \\
\text { recombinants }\end{array}$ & $\begin{array}{l}\text { No. of } \mathrm{Gal}^{+} \mathrm{McrB}^{+} \\
\text {clones tested }\end{array}$ \\
\hline $\begin{array}{l}30 \\
42\end{array}$ & $\begin{array}{c}0.003-0.02 \\
0 \cdot 1-1.0\end{array}$ & $\begin{array}{l}1 \cdot 2-0 \cdot 8 \\
0 \cdot 1-0 \cdot 004\end{array}$ & $\begin{array}{l}\mathrm{r}_{\mathrm{K}}^{+} \mathrm{m}_{\mathrm{K}}^{+} \\
\mathrm{r}_{\mathrm{K}}^{-} \mathrm{m}_{\mathrm{K}}^{-}\end{array}$ & 9 \\
\hline $\begin{array}{l}30 \\
42\end{array}$ & $\begin{array}{l}0.5-1.0 \\
0.8-1.0\end{array}$ & $\begin{array}{l}1.0-0.6 \\
0 \cdot 1-0.001\end{array}$ & $\begin{array}{l}\mathrm{r}_{\mathrm{K}}^{-} \mathrm{m}_{\mathrm{K}}^{+} \\
\mathrm{r}_{\mathrm{K}}^{-} \mathrm{m}_{\mathrm{K}}^{-}\end{array}$ & 3 \\
\hline
\end{tabular}

* The temperature of cultivation of bacteria before testing restriction and modification.

$\dagger$ Restriction indicates the e.o.p. of $\lambda v i r$. $O$ relative to $\lambda v i r . K$ (not included). Modification indicates the e.o.p. of phage produced by recombinants on $E$. coli $\mathrm{K}$ and $\mathrm{C}$ indicator strains. For each set of results the numbers represent the lowest and highest levels of e.o.p. of phage among the individual clones tested.

Table 3. Restriction and modification phenotypes of transformants obtained by transformation of $5 K-76-19\left(\right.$ hsd $\left.X_{\mathrm{ts}}^{+\mathrm{d}}\right)$ with hybrid $p B R 322$ plasmid DNA

\begin{tabular}{|c|c|c|c|c|c|}
\hline $\begin{array}{l}\text { Expt } \\
\text { no. }\end{array}$ & $\begin{array}{l}\text { Hybrid } \\
\text { plasmid }\end{array}$ & $\begin{array}{l}\text { Temp. } \\
\left({ }^{\circ} \mathrm{C}\right)^{*}\end{array}$ & $\begin{array}{l}\text { Restriction } \dagger \\
\quad \lambda \text { vir. } \mathrm{O}\end{array}$ & $\begin{array}{c}\text { Modification }+ \\
\text { K }\end{array}$ & $\begin{array}{l}\text { Phenotype of } \\
\text { transformants }\end{array}$ \\
\hline 1 & $\mathrm{pMS}_{\mathrm{K}} 14$ & $\begin{array}{l}30 \\
42\end{array}$ & $\begin{array}{l}0.01 \\
1.0\end{array}$ & $\begin{array}{l}0.5 \\
0.01\end{array}$ & $\begin{array}{l}\mathbf{r}_{\mathbf{K}}^{+} \mathbf{m}_{\mathbf{K}}^{+} \\
\mathbf{r}_{\mathbf{K}}^{-} \mathbf{m}_{\mathbf{K}}^{-}\end{array}$ \\
\hline 2 & $\mathrm{pMS}_{\mathrm{K}} \mathrm{C} 23$ & $\begin{array}{l}30 \\
42\end{array}$ & $\begin{array}{l}0.0003 \\
0.0003\end{array}$ & $\begin{array}{l}0.5 \\
1 \cdot 0\end{array}$ & $\begin{array}{l}\mathbf{r}_{\mathbf{K}}^{+} \mathrm{m}_{\mathbf{K}}^{+} \\
\mathbf{r}_{\mathbf{K}}^{+} \mathrm{m}_{\mathbf{K}}^{+}\end{array}$ \\
\hline 3 & $\mathrm{pMS}_{\mathrm{K}} \mathrm{V} 17$ & $\begin{array}{l}30 \\
42\end{array}$ & $\begin{array}{l}0.0002 \\
0.0003\end{array}$ & $\begin{array}{l}0 \cdot 7 \\
0.8\end{array}$ & $\begin{array}{l}\mathrm{r}_{\mathbf{K}}^{+} \mathrm{m}_{\mathbf{K}}^{+} \\
\mathrm{r}_{\mathbf{K}}^{+} \mathrm{m}_{\mathbf{K}}^{+}\end{array}$ \\
\hline
\end{tabular}

(Zinkevich et al., 1981; Ross \& Braymer, 1987), on which the $h s d X_{\mathrm{ts}}^{+\mathrm{d}}$ mutation could be located. Chromosomal DNA of $\mathrm{K} 802 \mathrm{Gal}^{+}$clone no. 6 was therefore digested with EcoRI and BamHI, ligated to EcoRI/BamHI-digested pBR322 and used to transform $\mathrm{CaCl}_{2}$-treated $E$. coli $\mathrm{K} 802$ cells. The advantage of the close linkage of $h s d X_{\mathrm{ts}}^{+\mathrm{d}}$ and $m c r B$ (Table 2) was used for direct selection of $\mathrm{McrB}^{+}$clones. The phage $\mathrm{T} 4 \alpha \mathrm{gt} 57 \beta g t 14$ (m.o.i. $\left.=1\right)$ was added and the cell suspension was plated on $\mathrm{L}$-agar with ampicillin. Among the $\mathrm{Ap}^{\mathrm{R}}$ colonies, the clone which 

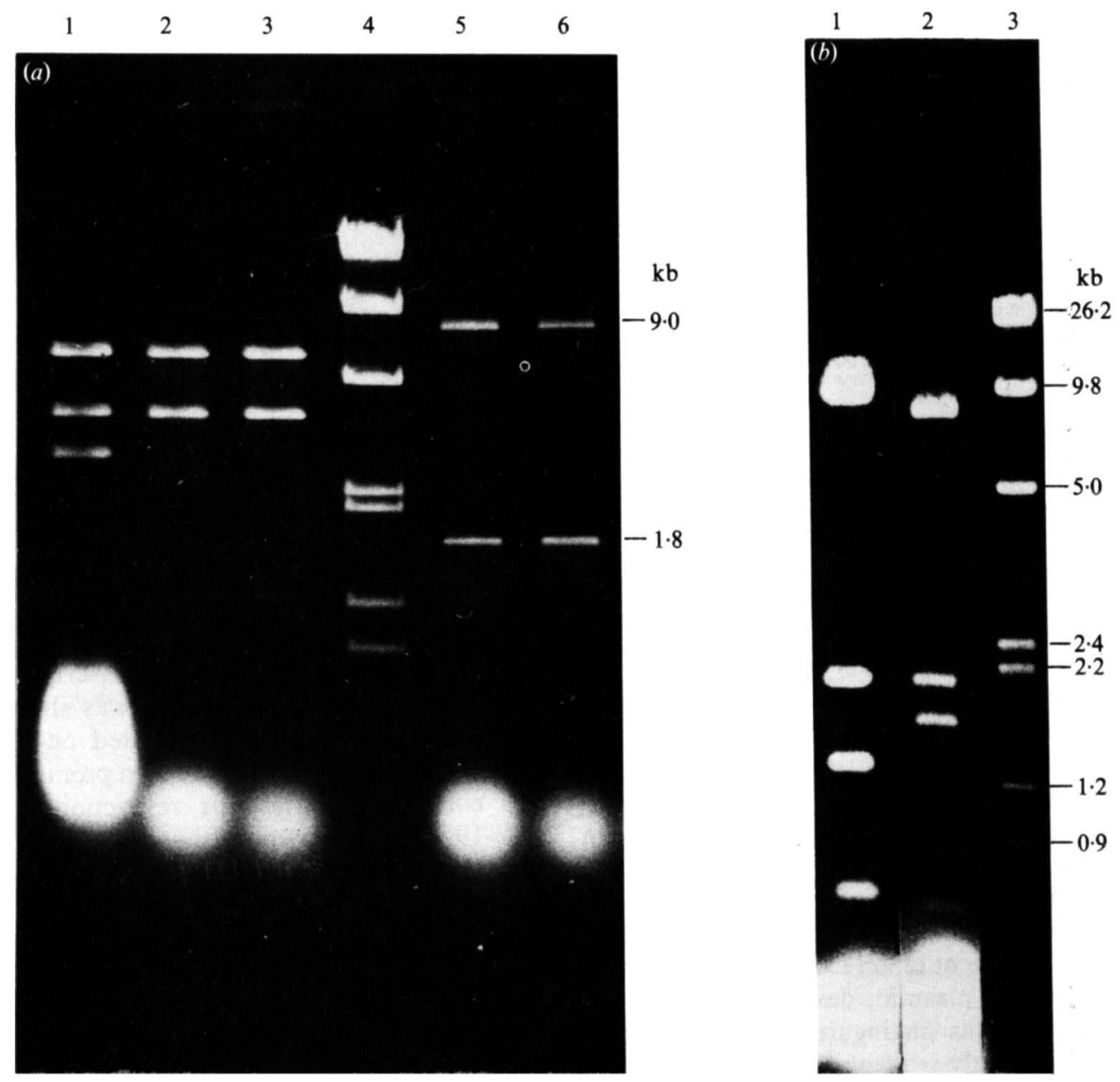

Fig. 2. Electrophoretic analysis of digests of DNA. The source of DNA and enzymes used to digest the DNA were as follows. (a) 1, pVM12,EcoRI + BamHI; 2, pVM $\Delta 2, E c o$ RI + BamHI; 3, pMS 14 ,

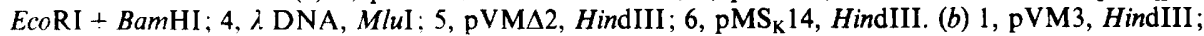
2.pVM16, HindIII; $3, \lambda$ DNA, MluI. Sizes of some fragments are given to the right of the photographs.

effectively restricted T4 $\alpha g t 57 \beta g t 14$ and $\lambda v i r . P v u I I$ phages was used for further analysis and detection of the unselected $\mathrm{HsdX_{ \textrm {ts } } ^ { + d }}$ phenotype. The plasmid DNA was extracted from the transformant, physically analysed and transformed into $E$. coli strain C600 (the plasmid was designated pVM12).

Restriction analysis showed the presence of an EcoRI-BamHI fragment (about $6.8 \mathrm{~kb}$ ) analogous to the fragment in plasmid $\mathrm{pMS}_{\mathrm{K}} 14$ isolated previously (Zinkevich et al., 1981); in addition to this fragment a BamHI fragment of unknown origin appeared in pVM12 (Fig. $2 a$, slot 1). $A p^{R} \mathrm{C} 600$ (pVM12) transformants were tested for restriction and modification of phage $\lambda$ at $30^{\circ} \mathrm{C}$ and $42{ }^{\circ} \mathrm{C}$. The results shown in Table 4, expt 2, demonstrate the slight trans-dominant effect of the $X_{\mathrm{ts}}^{+\mathrm{d}}$ mutation on the expression of the restriction phenotype. To demonstrate the precise location of the temperature-sensitive mutation it was necessary to cut out the additional BamHI fragment from the pVM12 DNA molecule. Digestion with BamHI, ligation, transformation of $E$. coli $\mathrm{C} 600$ and restriction analysis of isolated plasmid DNA yielded a hybrid pBR322 plasmid containing only the EcoRI-BamHI fragment (Fig. 2a, slot 2); this plasmid was designated $\mathrm{pVM} \Delta 2$. Functional analysis of the McrB and R-M phenotypes demonstrated the same level of expression of the McrB phenotype as observed with pVM12, while the transdominant effect of the $h s d X_{\mathrm{ts}}^{+\mathrm{d}}$ mutation disappeared (Table 4, expt 3 ). 
Table 4. Restriction and modification of $E$. coli strains with hybrid plasmids $p V M 12, p V M \triangle 2$, $p V M 3, p V M 16$ and $p V M 30$

$\begin{array}{clccc}\begin{array}{c}\text { Expt } \\ \text { no. }\end{array} & \text { Strain } & \begin{array}{c}\text { Temp. } \\ \left({ }^{\circ} \mathrm{C}\right)^{*}\end{array} & \begin{array}{c}\text { Restriction } \\ \lambda \text { vir. }\end{array} & \begin{array}{c}\text { Modification } \dagger \\ \mathrm{K}\end{array} \\ 1 & \mathrm{C} 600 & 30 & 0.0005 & 0.9 \\ & & 42 & 0.0002 & 1.0 \\ 2 & \text { C600(pVM12) } & 30 & 0.0004 & 0.7 \\ & & 42 & 0.001 & 1.0 \\ 3 & \text { C600(pVM } 2) & 30 & 0.0004 & 0.8 \\ & & 42 & 0.0007 & 0.6 \\ 4 & \text { C600(pVM3) } & 30 & 0.0005 & 1.0 \\ & & 42 & 0.05 & 0.06 \\ 5 & \text { C600(pVM16) } & 30 & 0.0001 & 0.8 \\ & & 42 & 0.0004 & 0.9 \\ 6 & \text { C600(pVM30) } & 30 & 0.0004 & 0.7 \\ & & 42 & 0.5 & 0.001\end{array}$

*† For details see the footnotes to Table 2.

Analysis of the primary structure of the $h s d M$ and $h s d S_{\mathrm{K}}$ genes revealed that the transcription of these genes starts from the common promoter $\mathrm{p}_{\text {mod }}$ (Loenen et al., 1987). It was shown previously (Zinkevich et al., 1981) that the expression of the hsdS gene located on the EcoRI-BamHI fragment cloned in pBR322 is inefficient due to the absence of its own promoter. Plasmid $\mathrm{pMS}_{\mathrm{K}} 14$ (Table 3 , expt 1) is unable to complement wild-type restriction and modification after transformation into strain $5 \mathrm{~K}-76-19$. We can assume, therefore, that in plasmid pVM $\Delta 2$ the $h s d X_{\mathrm{ts}}^{+\mathrm{d}}$ mutation is situated in the $h s d S$ gene and the low degree of its transdominant effect is a result of the inefficient transcription of this gene.

To improve the expression of the $h s d S$ gene we put it under the control of the $\lambda p_{R}$ promoter. A 2441 bp fragment of $\lambda c I 857$ was inserted into the BamHI site of plasmid pVM $\Delta 2$ (Fig. $3 a-d$ ). The resulting plasmid, designated pVM3 (Fig. $3 d$ ), with the $B g$ lII fragment in the correct orientation, was distinguished from the plasmids with the opposite orientation by HindIII restriction analysis of plasmid DNA and by the trans-dominant effect on the restriction and modification phenotype of transformed cells exerted by the $X_{\mathrm{ts}}^{+\mathrm{d}}$ mutation. Plasmid pVM3 revealed, after HindIII restriction, a new fragment $(1.4 \mathrm{~kb})$ generated by joining the BamHI-HindIII part of the cloned BamHI-EcoRI fragment with the BglII-HindIII part of the $\lambda$-controlling region (Fig. 2b, slot 1). The C600(pVM3) Ap ${ }^{\mathrm{R}}$ transformant, temperature-sensitive in restriction and modification, clearly demonstrated the trans-dominant effect of the $X_{\mathrm{ts}}^{+\mathrm{d}}$ mutation on the expression of the R-M phenotype (Table 4, expt 4).

The expression of the $h s d X_{\mathrm{ts}}^{+\mathrm{d}}$ gene under the control of the $\lambda \mathrm{p}_{\mathrm{R}}$ promoter in $E$. coli P678-54(pVM3) minicells grown at different temperatures was determined as follows. Cell-free homogenates from minicells labelled with ${ }^{14} \mathrm{C}$-amino acids were analysed by SDS-PAGE and autoradiography. Computer-assisted image analysis of the resulting autoradiogram allowed quantification of the product of the $h s d$ gene among other labelled proteins (Vohradsky et al., 1988). The results (Fig. $3 g$ ) show that, due to the effect of $c I 857$ on the $\lambda p_{R}$ promoter, the formation of the $h s d S$ gene product increases when the temperature of cultivation is raised from $28^{\circ} \mathrm{C}$ to $37^{\circ} \mathrm{C}$ and $42^{\circ} \mathrm{C}$.

In the next experiment the $B g l \mathrm{II} \lambda$ fragment was inserted in the same orientation into the $B g l$ II site inside the $h s d S$ gene, leading to its interruption (Fig. $2 b$, slot 2; Fig. $3 f$ ); the resulting plasmid was designated pVM16. In this case the trans-dominant effect of the $X_{\mathrm{ts}}^{+\mathrm{d}}$ mutation disappeared (Table 4, expt 5).

Plasmid pVM3 still carries a large region of the cloned EcoRI-BamHI fragment downstream of the $h s d S$ gene. To exclude the possibility that the $X_{\mathrm{ts}}^{+\mathrm{d}}$ mutation could be located in this region, the HpaI-EcoRI part of the cloned EcoRI-BamHI fragment was deleted (Fig. 3e; plasmid designated pVM30). If the mutation lies in this region, the trans-dominant effect of the $X_{\mathrm{ts}}^{+\mathrm{d}}$ 
(a)

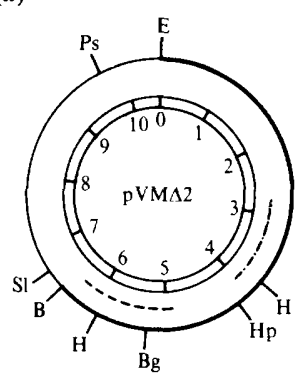

(b)

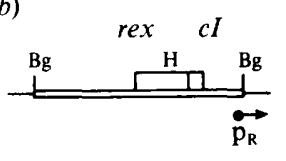

(c)

$(d)$

(e)
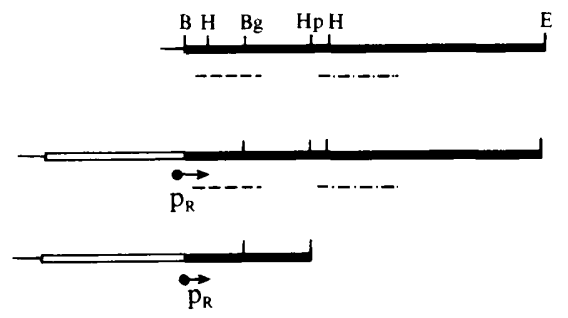

$(f)$

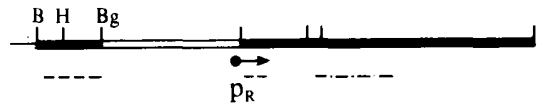

$(g)$

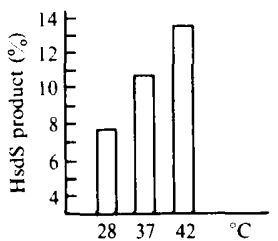

Fig. 3. (a-f) Restriction maps of the hybrid plasmids pVM $\Delta 2$, pVM3, pVM16 and pVM30. (a) Restriction map of plasmid pVM $\Delta 2$. The internal size scale is in $\mathrm{kb}$. (b) $B g / \mathrm{II}$ fragment of $\lambda$ phage. (c) BamHI-EcoRI chromosomal fragment of pVM $\Delta 2$. (d) Plasmid pVM3: BglII fragment of $\lambda$ phage cloned into the BamHI site of pVM $\Delta 2$. (e) Plasmid pVM30: HpaI-EcoRI region of pVM3 deleted. $(f)$ Plasmid pVM16: Bg/II fragment of $\lambda$ phage cloned into the BglII recognition site within the $h s d S_{\mathrm{ts}}^{+\mathrm{d}}$ gene. - - pBR322 DNA; $-B a m H I-E c o$ RI chromosomal fragment; $\square, B g l I$ fragment of $\lambda$ phage; ----, hsd $S$ gene; -.-.-, mcrB gene; the arrows indicate the direction of transcription from $\mathrm{p}_{\mathrm{R}}$. Restriction enzymes: E, EcoRI; H, HindIII; Hp, HpaI; Bg, BglII; B, BamHI; Sl, SalI; Ps, PstI.

(g) Level of $h s d S_{\mathrm{ts}}^{+\mathrm{d}}$ gene expression at cultivation temperatures of $28^{\circ} \mathrm{C}, 37^{\circ} \mathrm{C}$ and $42^{\circ} \mathrm{C}$. The amount of HsdS protein is expressed as a fraction of the total labelled proteins at the respective temperature.

mutation on restriction and modification should be eliminated. In fact the trans-dominant effect was still apparent (Table 4, expt 6), a result that supports the location of the mutation in the $h s d S$ gene; no other open reading frame is present in plasmid pVM30 with the HpaI-EcoRI deletion (Gough \& Murray, 1983).

\section{Level of $H s d S$ and $H s d S_{\mathrm{ts}}^{+\mathrm{d}}$ products in the cell and expression of the $R-M$ phenotype}

If the $X_{\mathrm{ts}}^{+\mathrm{d}}$ mutation is within the $h s d S$ gene, the question arises how it 'controls' the expression of restriction and modification. One can assume that the mechanism of action of the $X_{\mathrm{ts}}^{+\mathrm{d}}$ mutation is based on the level of synthesis of the $\gamma$ subunit, the product of the $h s d S$ gene, which is structurally modified, especially at higher temperatures, as a result of the substitution of one amino acid for another in a critical part of the HsdS protein. To compare the effect of different levels of $\mathrm{HsdS}$ and $\mathrm{Hsd} \mathrm{S}_{\mathrm{ts}}^{+\mathrm{d}}$ products on the expression of the R-M phenotype, we constructed partial $\mathrm{F}^{\prime}$ diploids with the wild-type or the mutated $h s d S$ gene and with the $X_{\mathrm{ts}}^{+\mathrm{d}}$ mutation, both situated either on the bacterial chromosome or on the $F^{\prime}$-plasmid. 
Table 5. Restriction and modification phenotypes of $F^{\prime}$ merodiploids

The $F^{\prime}$ elements were equally stable at $30^{\circ} \mathrm{C}$ and $42{ }^{\circ} \mathrm{C}$; at both temperatures more than $95 \%$ of cells carried the $\mathrm{F}^{\prime}$ plasmid at the time of phage $\lambda v i r . \mathrm{O}$ addition.

\begin{tabular}{|c|c|c|c|c|c|c|}
\hline \multirow[b]{2}{*}{$\begin{array}{l}\text { Expt } \\
\text { no. }\end{array}$} & \multicolumn{2}{|c|}{ Haploid phenotype } & \multirow[b]{2}{*}{$\begin{array}{l}\text { Temp. } \\
\left({ }^{\circ} \mathrm{C}\right)^{*}\end{array}$} & \multirow[b]{2}{*}{$\begin{array}{l}\text { Restriction } \dagger \\
\quad \lambda \text { vir. } \mathrm{O}\end{array}$} & \multirow[b]{2}{*}{$\underset{\mathbf{K}}{\text { Modification } \dagger}$} & \multirow[b]{2}{*}{$\begin{array}{l}\text { Phenotype of } \\
\text { merodiploid }\end{array}$} \\
\hline & Recipient & $F^{\prime}$ & & & & \\
\hline \multirow[t]{3}{*}{1} & $\begin{array}{l}\text { AB2463 } \\
h s d S^{+}\end{array}$ & $\begin{array}{l}90-\mathrm{XC} \\
X_{\mathrm{ts}}^{+\mathrm{d}}\end{array}$ & & & & \\
\hline & $\mathrm{r}_{\mathrm{K}}^{+} \mathrm{m}_{\mathrm{K}}^{+}$ & $\mathrm{r}_{\mathbf{K}}^{+} \mathrm{m}_{\mathrm{K}}^{+}$ & 30 & 0.003 & 0.8 & $\mathrm{r}_{\mathrm{K}}^{+} \mathrm{m}_{\mathrm{K}}^{+}$ \\
\hline & $\mathrm{r}_{\mathrm{K}}^{+} \mathrm{m}_{\mathrm{k}}^{+}$ & $\mathrm{r}_{\overline{\mathbf{k}}} \mathrm{m}_{\overline{\mathbf{K}}}$ & 42 & 0.2 & 0.6 & $\mathrm{r}_{\mathrm{K}}^{-} \mathrm{m}_{\mathrm{K}}^{+}$ \\
\hline \multirow[t]{3}{*}{2} & $\begin{array}{l}\text { IV-28-1 } \\
h s d S^{-}\end{array}$ & $\begin{array}{l}90-\mathrm{XC} \\
X_{\mathrm{ts}}^{+\mathrm{d}}\end{array}$ & & & & \\
\hline & $\mathrm{r}_{\overline{\mathrm{K}}} \mathrm{m}_{\overline{\mathrm{K}}}$ & $\mathrm{r}_{\mathrm{K}}^{+} \mathrm{m}_{\mathrm{K}}^{+}$ & 30 & 0.003 & $0 \cdot 3$ & $\mathrm{r}_{\mathrm{K}}^{+} \mathrm{m}_{\mathrm{K}}^{+}$ \\
\hline & $\mathrm{r}_{\overline{\mathrm{K}}} \mathbf{m}_{\overline{\mathrm{K}}}$ & $\mathrm{r}_{\overline{\mathrm{K}}} \mathrm{m}_{\overline{\mathrm{K}}}$ & 42 & 0.2 & 0.07 & $\mathrm{r}_{\mathrm{K}}^{-} \mathrm{m}_{\overline{\mathrm{K}}}^{-}$ \\
\hline \multirow[t]{3}{*}{3} & $\begin{array}{l}5 \mathrm{~K}-76-19 \ddagger \\
X_{\mathrm{ts}}^{+\mathrm{d}}\end{array}$ & $\begin{array}{l}\mathrm{KLF} 1 \\
h s d S^{+}\end{array}$ & & & & \\
\hline & $\mathrm{r}_{\mathrm{K}}^{+} \mathrm{m}_{\mathrm{K}}^{+}$ & $\mathrm{r}_{\mathrm{k}}^{+} \mathrm{m}_{\mathrm{k}}^{+}$ & 30 & 0.0001 & 0.7 & $\mathrm{r}_{\mathrm{K}}^{+} \mathrm{m}_{\mathrm{K}}^{+}$ \\
\hline & $\mathrm{r}_{\mathbf{K}} \mathrm{m}_{\overline{\mathrm{K}}}$ & $\mathrm{r}_{\mathrm{K}}^{+} \mathrm{m}_{\mathrm{K}}^{+}$ & 42 & 0.0006 & 0.8 & $\mathrm{r}_{\mathrm{K}}^{+} \mathrm{m}_{\mathrm{K}}^{+}$ \\
\hline \multirow[t]{3}{*}{4} & $\begin{array}{l}5 \mathrm{~K}-76-19 \ddagger \\
X_{\text {is }}^{+d}\end{array}$ & $\begin{array}{l}\text { IV } \\
h s d S^{-}\end{array}$ & & & & \\
\hline & $\mathrm{r}_{\mathrm{K}}^{+} \mathrm{m}_{\mathrm{k}}^{+}$ & $\mathrm{r}_{\mathrm{K}} \mathrm{m}_{\overline{\mathrm{K}}}$ & 30 & 0.0006 & $1 \cdot 0$ & $\mathrm{r}_{\mathrm{K}}^{+} \mathrm{m}_{\mathrm{K}}^{+}$ \\
\hline & $\mathrm{r}_{\overline{\mathrm{K}}} \mathrm{m}_{\overline{\mathrm{K}}}^{-}$ & $\mathrm{r}_{\overline{\mathrm{K}}} \mathrm{m}_{\overline{\mathrm{K}}}$ & 42 & 0.6 & 0.0003 & $\mathrm{r}_{\mathbf{K}}^{-} \mathrm{m}_{\overline{\mathrm{K}}}^{-}$ \\
\hline
\end{tabular}

* $†$ For details see the footnotes to Table 2.

$\ddagger$ The recipient strain $5 \mathrm{~K}-76-19$ was prepared from $\mathrm{C} 600-5 \mathrm{~K}$ as a $\mathrm{Thr}^{+} \mathrm{HsdX}_{\mathrm{ts}}^{+\mathrm{d}}$ cotransductant to which the rec $A$ mutation was introduced by conjugation with $\mathrm{HfrJC} 5088$ as donor strain.

The trans-dominant effect of the $X_{\mathrm{ts}}^{+\mathrm{d}}$ mutation on the restriction phenotype was obtained in diploids using recipients with wild-type $h s d S$ as well as mutated $h s d S$ alleles (Table 5, expts 1 and 2 ), while the effect on $\mathrm{K}$-specific modification was observed only in the diploid with $h s d S^{-}$ recipient (Table 5, expt 2) or in $h s d S^{+}$cells with the $X_{\mathrm{ts}}^{+\mathrm{d}}$ mutation located on the hybrid multicopy pVM3 plasmid (Table 4, expt 4). In reciprocal partial diploids, with the $X_{\mathrm{ts}}^{+\mathrm{d}}$ mutation located on the recipient chromosome, the temperature-sensitive R-M phenotype was detected only in experiment 4 , (Table 5), while the diploid with the $h s d S^{+}$allele on the $\mathrm{F}^{\prime}$ element displayed the wild-type R-M phenotype (Table 5, expt 3). The results indicate that the transdominant effect of the $X_{\mathrm{ts}}^{+\mathrm{d}}$ mutation depends on the ratio of $\mathrm{HsdS}^{+}$and $\mathrm{S}_{\mathrm{ts}}^{+\mathrm{d}}$ products. The higher sensitivity of the expression of restriction to the effect of the $\mathrm{HsdS}_{\mathrm{ts}}^{+\mathrm{d}}$ product as compared to the modification phenotype could reflect different quantitative aspects of interaction of the protein subunits during the formation of R.EcoK and M.EcoK enzymes or their recognition properties.

We thank Ing. J. Vohradský for quantification of autoradiographs by means of computer-assisted image analysis.

\section{REFERENCES}

AdLer, H. I., Fisher, W. D., COHEN, A. \& HARDIGREe, A. A. (1967). Miniature Escherichia coli cells deficient in DNA. Proceedings of the National Academy of Sciences of the United States of America 57, 321-326.

Bolivar, R., Rodriguez, R. L., Greene, P. J., Betlach, M. L., Heynecker, A. L., Boyer, H. V., Crosa, J. H. \& Falkow, S. (1977). Construction and characterization of new cloning vehicles. II. A multipurpose cloning system. Gene 2, 95-113.

BOYER, H. W. \& Roulland-DussoIX, D. (1969). A complementation analysis of the restriction and modification of DNA in Escherichia coli. Journal of Molecular Biology 41, 459-472.

Burckhardt, J., WeisemanN, J., Hamilton, D. L. \& YUAN, R. (1981). Complexes formed between the restriction endonuclease $E c o \mathrm{~K}$ and heteroduplex DNA. Journal of Molecular Biology 153, 425-440.

Gough, J. A. \& Murray, N. E. (1983). Sequence diversity among related genes for recognition of specific targets in DNA molecules. Journal of Molecular Biology 166, 1-19. 
HubÁČEK, J. (1973). Functional analysis of second-step host specificity mutations in unstable Escherichia coli heterozygotes. Journal of General Microbiology 79, 257-264.

HubáČeK, J. \& Glover, S. W. (1970). Complementation analysis of temperature-sensitive host specificity mutations in Escherichia coli. Journal of Molecular Biology 50, 111-127.

HubÁČEK, J. \& KOSSYKH, V. G. (1982). Transdominant mutation affecting restriction and modification in Escherichia coli K12. Molecular and General Genetics 187, 459-460.

HubÁČEK, J. \& WeISERovÁ, M. (1980). DNA restriction and modification in Escherichia coli: functional analysis of the role of the $\operatorname{dnaC}(D)$ gene product. Journal of General Microbiology 119, 231-238.

HuBÁČEK, J. \& WeISERovÁ, M. (1985). Biological function of type I restriction enzymes. In Proceedings of the International Symposium on Gene Manipulation and Expression, pp. 95-109. Edited by R. E. Glass \& J. Spižek. London: Croom-Helm.

Loenen, W. A. M., Daniel, A. S., Braymer, H. D. \& MURRAY, N. E. (1987). Organization and sequence of the hsd genes of Escherichia coli K-12. Journal of Molecular Biology 198, 159-170.

Maniatis, T., Fritsch, E. F. \& Sambrook, J. (1982). Molecular Cloning. A Laboratory Manual. Cold Spring Harbor, NY: Cold Spring Harbor Laboratory.

MARmUR, J. (1961). A procedure for the isolation of deoxyribonucleic acid from microorganisms. Journal of Molecular Biology 3, 208-218.

Raleigh, E. A. \& Wilson, G. (1986). Escherichia coli K12 restricts DNA containing 5-methylcytosine. Proceedings of the National Academy of Sciences of the United States of America 83, 9070-9074.

Raleigh, E. A., Murray, N. E., Revel, H., Blumenthal, R. M., Westaway, D., Reith, A. D., Rigby, P. W. J., Elhai, J. \& Hanahan, D. (1988). McrA and McrB restriction phenotypes of some $E$. coli strains and implications for gene cloning. Nucleic Acids Research 16, 1563-1575.
Ravi, R. S., Sozhamannan, S. \& Dharmalingam, K. (1985). Transposon mutagenesis and genetic mapping of the rglA and $\mathrm{rg} / \mathrm{B}$ loci of Escherichia coli. Molecular and General Genetics 198, 390-392.

ROSNER, J. L. (1972). Formation, induction and curing of bacteriophage P1 lysogens. Virology 48, 679-689.

Ross, T. K. \& BRAYMER, H. D. (1987). Localization of a genetic region involved in $\mathrm{McrB}$ restriction by Escherichia coli K-12. Journal of Bacteriology 169, 1757-1759.

Ruther, U., KoEnen, M., OtTo, K. \& MÜlleR-Hill, B. (1981). pVRC222, a vector for cloning and rapid chemical sequencing of DNA. Nucleic Acids Research 9, 4087-4098.

SaIN, B. \& Murray, N. E. (1980). The hsd (host specificity) genes of E. coli K12. Molecular and General Genetics 180, 35-46.

VAN PAL, A. \& Colson, C. (1974). DNA restriction and modification systems in Salmonella. II. Genetic complementation between the $\mathbf{K}$ and $\mathbf{B}$ systems of Escherichia coli and the Salmonella typhimurium system SB, with the same chromosomal location. Molecular and General Genetics 135, 51-60.

VOHRADSKÝ, J., WeISER, J. \& JANDA, I. (1988). An image analysis system controlled by a personal computer: application to monitoring of protein biosynthesis in Streptomyces aureofaciens. In 2nd International Symposium on Overproduction of Microbial Products, Abstract Book, p. 236. Prague : Czechoslovak Academy of Sciences.

Zinkevich, V. E., Solonin, A. S., Bogdarina, I. G., TANiashin, V. I. \& BAYEV, A. A. (1981). Cloning and restriction analysis of DNA fragment BamHIEcoRI containing genes of $h$ sd-regions of Escherichia coli. Dokladi Akademii Nauk SSSR 259, 216-218.

ZINKEVICH, V. E., ZOGRAF, YU. N. \& TANIASHIN, V. I. (1984). Genes of DNA-methylase EcoK : cloning and expression. Dokladi Akademii Nauk SSSR 279, 1493-1496. 